\title{
Sjögren 症候群における唾液腺造影像と免疫学的検査所見との関連
}

\author{
斎藤徹・福田博・有末真*・松田曙美*

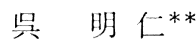

\section{Relationship between sialographical and immunological findings of Sjögren's syndrome}

\author{
Tohru SAito • Hiroshi Fukuda - Makoto Arisue* \\ Akemi Matsuda* . Akihito KurE**
}

\begin{abstract}
Sjögren's syndrome (SS) based on sialogram of the parotid gland and were diagnosed as not having other autoimmune diseases, were evaluated in order to clarify the relationship of the sialographical appearance to immunological findings of SS.

According to Fukuda's sialographical classification for SS (Class I-Class VV), the patients were classified into three groups. 21 patients were classified as Class II, which suggests an early stage of SS. 8 patients were classified into Class $\mathbb{I I}$ and 13 into Class $\mathbb{V}$, which suggest advanced stages for SS. Class I was not observed in this group of patients. Numbers of both peripheral blood leukocytes (leu) and lymphocytes (lym) of Class VV patients (leu: 4, 200/ $\mathrm{mm}^{3}$, lym: $1,400 / \mathrm{mm}^{3}$ ) were significantly lower than those of Class II patients (leu: 5,900/ $\mathrm{mm}^{3}$, lym: $\left.1,900 / \mathrm{mm}^{3}\right)$. Increase in $\gamma$-globulin, IgA, IgG and IgM in the sera of the patients was also observed as the sialographical classification advanced. Serum anti-nuclear antibody (ANA) and rheumatoid factor (RF) were observed in $43 \%$ and $38 \%$ of Class II patients, $63 \%$ and $50 \%$ of Class III patients, and $67 \%$ and $75 \%$ of Class V patients, respectively. A high incidence of ANA and RF were observed also in Class II patients, and increases in the incidence of the above factors were seen as the sialographical classification advanced. Serum anti-SS-A antibody and anti-SS-B antibody were demonstrated in $57 \%$ and $29 \%$ of Class $\mathbb{I I}$ patients, and $88 \%$ and $38 \%$ of Class IV patients. In contrast, the above antibodies were not observed in the sera of Class II patients.
\end{abstract}

Key words: Sjögren's syndrome (Sjögren 症候群), sialographical appearances (唾液腺造影像), immunological findings (免疫学的検査所見)

北海道大学碀学部口腔外科学第 1 䍀㭫 （主任：福田 博教授）

* 北海道大学粨学部口腔外科学第 2 满座 （主任：河村正昭教授）

**北海道大学㳡学部荬科放射線学講座 （主任：山崎岐男教授）

First Department of Oral Surgery, Hokkaido University School of Dentistry (Chief: Prof.
Hiroshi Fukuda)

* Second Department of Oral Surgery, Hokkaido University School of Dentistry (Chief: Prof. Masaaki Kawamura)

** Department of Dental Radiology, Hokkaido University School of Dentistry (Chief: Prof. Mikio Yamazaki)

受付日：平成元年 3 月 3 日 
緒

言

Sjögren 症候群 (SS) は口腔乾燥, 乾燥性角結膜炎 (KCS) などの乾燥症状を主徵とし，これにRAなどの 自己免疫疾患を合併する全身性疾患と考えられているい 4) SS に扎いても他の自己免疫疾患之同様に種々の免 疫異常が出現することが知られている。すすなわち，SS 患者においては，血清抗核抗体 ${ }^{4,5}$, リウマトイド因子 $(\mathrm{RF})^{4,5)}$, 抗 SS-A 抗体・抗 SS-B 抗体 ${ }^{4 \sim 6)}$ などの自己

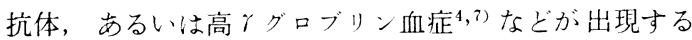
ことが知られている。束た，末梢血りンパ球の減少〕およ び， CD 4 陽性細胞/CD 8 陽性細胞比の上昇 ${ }^{8,9)}$ あるいは

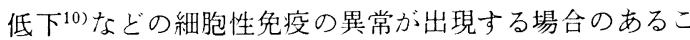
とが報告されている。しかしここれらの免疫学的異常と， SS にお忛る臨床症状あるいは唾液腺の病理組織学的所 見, 唾液腺造影像 (唾影像) 所見などとの関連性を検索 した報告は少ない，本研究においては，SS における唾 液腺の病変を検索する方法として耳下腺造影法 ${ }^{11,12)}$ を用 い, 唾影像所見と患者の全身的な免疫異常の関連性を検 索し, SS の診断における唾影像の意義を再検討した。

\section{対象および方法}

対象：昭和60年か562年の間に当科に来院し，唾液腺 造影に上り SS を疑わせ，加他の自己免疫疾患を伴わ ない患者を対象とした，患者は17歳から63歳までの42名 であり，女性38名，男性4名であった。

唾液腺造影法 : 76\%ウログラフィンを $0.15 \mathrm{ml} / 10$ 秒の 速度で総量 $2.0 \mathrm{ml}$ を耳下腺に持続注入しながら, 同時

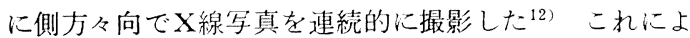
って得られた管系適量像および腺系適量像を観察し福田

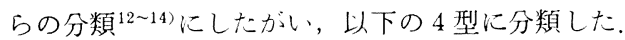

I 型：末梢導管の昖張㧍よび均質な腺系像

II 型: 末梢導管の抬張および不均質な斑紋状の腺系像

III型：末梢導管の拡張拈よび無数の点状陰影を含む腺 外形の比䡆的明膫な腺系像

IV 型：末梢導管の抾張㧍よび無数の小円型院影を有 し, 外形の不明膫な腺系像

眼科的診断：KCS は本学医学部附属病院眼科法 Schirmer 法, Fluorescein 染色扰上び Rose-Bengal 染色 にもとづき診断された。

10\%クエン酸による耳下腺刺激唾夜分泌量の測定： Modified Carlson-C'rittenden Cup ${ }^{15)}$ を下腺開口部に 装着後, $10 \%$ クェン酸を 10 秒毎に $0.03 \mathrm{ml}$ 年つ 5 分間舌 背部に滴下し，導出したチューブより流出する唾液を採 取計量した。また，臨床的および血清学的に異常の認め られない20６00代の女性75名を健常人の対照群とし $た^{12,16)}$.
表 1 各病型の年齡拉よび性別分布

\begin{tabular}{c|c|c|c}
\hline 年齢 & 病型 & II & IV \\
\hline $10 \sim 19$ & & 1 & \\
$20 \sim 29$ & $4(1)$ & & 2 \\
$30 \sim 39$ & 4 & 1 & 3 \\
$40 \sim 49$ & $6(2)$ & 2 & 4 \\
$50 \sim 59$ & 6 & 3 & 4 \\
$60 \sim$ & $1(1)$ & 1 & \\
\hline 計 & $21(4)$ & 8 & 13 \\
\hline
\end{tabular}

（）：男性数

耳下腺および口唇腺の病理組織学的検索 : 試験切除標 本は通法により $10 \%$ 中性ホルマリンにて固定後パラフィ ン包埋し, 約 $5 \mu$ の切片を製作した後，へマトキシリ ン・エオジン染色を行い観察した。耳下腺掞よびロ唇腺 の病理組織学的検索は, 主に導管周囲性のリンパ球浸㵎 などの変化 ${ }^{17,18)}$ ともとづいた。

血清 $\curlyvee$ グロブリンおよび IgA，IgG，IgM の定量：血

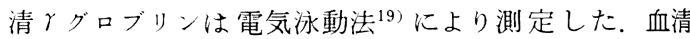
$\operatorname{IgA} ， \operatorname{IgG}$ およびIgM は単純免疫拡散法 ${ }^{20)}$ により測定 した.

血清抗核抗体の検出 : HEp-2 培盖細胞（ヒト喉頭癌 由来）を基質として，螢光抗体間接法を用いて抗核抗体 を検出した ${ }^{21}$

血清 RF の検出：ラテックス粒子にヒトケグロブリン を吸着させたグロブリン乳液と，血清中の RF との受身 凝集反応 ${ }^{22}$ させることにより RFを検出した。

血清抗 SS-A 抗体および抗 SS-B 抗体の検出: 動物捗 器から抽出した二種の抗原を用い, アガロース・ゲル中 での二重免疫拡散法（オクタロニ一法）の沈降反応によ り, 抗 SS-A 抗体拈よび抗 SS-B 抗体を検出した ${ }^{23)}$.

$$
\text { 結果 }
$$

\section{唾影像により SS を疑わせた症例の年撂および性別分} 布

耳下腺唾影像によりSS を疑わせた症例中，II 型は21 例であり，III，IV型に分類された症例はそれぞれ8例， 13例であった。本研究においてはI 型は認められなかっ た。亦た，各病型ともに大多数の患者が 20 ～ 50 代であっ た（表 1 )

\section{各病型における臨床および唾液腺の病理組織学的所見}

KCS 之䛦断された症例は，II 型：50\%，林型： $83 \%$, IV型：70\%であり，唾影像上の病型のいかんにかかわら ず高值を示した。李た，10\%クェン酸による耳下腺刺激 唾液分泌量は, II 型: $3.3 \pm 1.5 \mathrm{ml} / 5$ 分, III 型: $2.1 \pm$ $1.1 \mathrm{~m} / / 5$ 分, $\mathbb{V}$ 型: $3.3 \pm 1.5 \mathrm{~m} / / 5$ 分であった。健常 
表 2 各病型と臨休所見扣よび唾液腺の病理組織学: 的所見との断連

\begin{tabular}{|c|c|c|c|}
\hline 病型 & $\begin{array}{c}\mathrm{KCS} \text { 合悦 } \\
\text { Lた症例数/ } \\
\text { 検査症例数 } \\
(\%)\end{array}$ & $\begin{array}{l}\text { 耳下腺の刺激 } \\
\text { 唾液分泌量/ } \\
5 \text { 分 } \\
\text { Mean } \pm \text { SD }\end{array}$ & 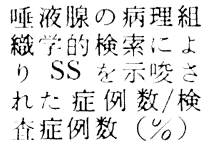 \\
\hline II & $10 / 20(50)$ & $3.3 \pm 1.5^{a}$ & $6 / 21 \quad(29)$ \\
\hline III & $5 / 6(83)$ & $2.1 \pm 1.1^{\mathrm{b}}$ & $7 / 8 \quad(88)$ \\
\hline $\begin{array}{c}\mathrm{T} \\
\text { 健常人 }\end{array}$ & $7 / 10(70)$ & $\begin{array}{l}3.3 \pm 1.5^{\mathrm{c}} \\
4.5 \pm 1.5^{\mathrm{a}, \mathrm{b}, \mathrm{c}}\end{array}$ & $12 / 13(92)$ \\
\hline
\end{tabular}

$\mathrm{a}, \mathrm{b}, \mathrm{c}:$ Statistically significant $(\mathrm{a}: \mathrm{p}<0.005, \mathrm{~b}:$ $\mathrm{p}<0.001$, c : p $<0.05$ ), by Student's t-test.

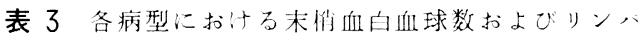
球数

\begin{tabular}{c|c|c}
\hline 病 型 & $\begin{array}{c}\text { 由血球数 } / \mathrm{mm}^{3} \\
\text { Mean } \mathrm{SD}\end{array}$ & $\begin{array}{c}\text { リン・球数 } / \mathrm{mm}^{3} \\
\text { Mean } \pm \mathrm{SD}\end{array}$ \\
\hline II & $5,900 \pm 2,500^{\mathrm{a}}$ & $1,900 \pm 800^{\mathrm{b}}$ \\
III & $5,000 \pm 1,700$ & $1,500 \pm 400$ \\
IV & $4,200 \pm 900^{\mathrm{a}}$ & $1,400 \pm 500^{\mathrm{b}}$ \\
\hline
\end{tabular}

$\mathrm{a}, \mathrm{b}:$ Statistically significant $(\mathrm{a}: \mathrm{p}<0.001, \mathrm{~b}: \mathrm{p}<$ 0.005 ), by Student's t-test.

人: $4.5 \pm 1.5 \mathrm{ml} / 5$ 分と比較して, すべての病型におい て有意の低下が認められた（II 型： p < 0.005，四型 $\mathrm{p}<0.001 ， \mathrm{~V}$ 型 $\cdot \mathrm{p}<0.05)$ ，耳下腺あるいは口唇腺の 病理組織学的模索により，少なくとも一力に SS を示㖫 する所見が得られた症例は，II 型：29\%，向型：88\%， IV型：92\%であり，進行病型（四、V型）では高值を示 したが, 初期病型（II 型）では低俻であった（表 2 ）.

\section{各病型における末梢血白血球数およびリンパ球数}

各病型にお汁る末梢血白血球数は, II 型：5,900土 $2,500 / \mathrm{mm}^{3}$, III 型 : 5, $000 \pm 1,700 / \mathrm{mm}^{3}$, IV 型 : 4, $200 \pm$ 900/ $\mathrm{mm}^{3}$ であり, 唾影像上の病型の進行に伴ら低下が

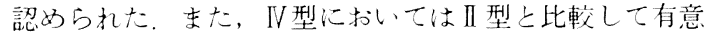
に（ $\mathrm{p}<0.001 ）$ 低下していた（表了）。同様に，末梢血 リンパ球数は, II 型: $1,900 \pm 800 / \mathrm{mm}^{3}$, II 型: $1,500 \pm$

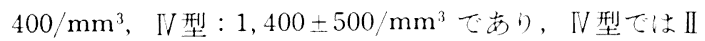
型と比較して有意 $(\mathrm{p}<0.005)$ に低下していた（表 3 ).

\section{各病型における血清 $\curlyvee$ グロブリン量}

唾影像上の病型の進行に伴い血清とグロフンン分画は 増加し， V型 $(25.6 \pm 4.1 \%)$ に拈いては，II 型（16.1 土4. $9 \%$ ）および II 型 $(19.2 \pm 3.9 \%)$ と比較して有意な 増加が認められた（IV vs II : p <0.001, IV vs III : p $<0.005)$ （表 4 ）。また，血清 IgA，IgG、Ig.M 病型 の進行に伴い増加し、 V 型においては II 型と比较して IgA，IgG，IgM 共に有意な増加が認められた（IgA .
表 4 各病型に扣㤃る血清とタロブリン量

\begin{tabular}{|c|c|c|c|c|}
\hline 病型 & 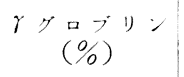 & $\underset{\mathrm{mg} / \mathrm{d} l}{\mathrm{IgA}}$ & $\underset{\mathrm{mg} / \mathrm{dg} l}{\mathrm{IgG}}$ & $\underset{\mathrm{mg} / \mathrm{d} l}{\mathrm{IgM}}$ \\
\hline II & $16.5 \pm 4.9^{\mathrm{a}, \mathrm{b}}$ & $246 \pm 111^{\mathrm{d}}$ & $1,609 \pm 474^{\mathrm{e}}$ & $237 \pm 178$ \\
\hline III & $19.2 \pm 3.9^{c}$ & $310 \pm 101$ & $1,844 \pm 270$ & $242 \pm 54$ \\
\hline TV & $25.6 \pm 4.1^{\mathrm{d}, c}$ & $372 \pm 119^{d}$ & $2,385 \pm 429^{e}$ & $278 \pm 105$ \\
\hline \multicolumn{5}{|c|}{$\begin{array}{l}\text { a : Mean } \pm \text { SD. } \\
\text { b, c, d, e, f: Statistically significant (b, d, e : p }< \\
0.001, \quad \text {, f : p }<0.005), \quad \text { by Student's }\end{array}$} \\
\hline
\end{tabular}

表 5 各病型に扣外る血清抗核抗体, RF, 抗 SS-A 抗体, 抗 SS-B 抗体の陽性率

\begin{tabular}{c|c|c|c|c|c}
\hline \multirow{2}{*}{ 病型 } & \multicolumn{3}{|c|}{ 陽性で市った症例数/検査症例数 $(\%)$} \\
\cline { 2 - 6 } & 抗核抗体 & RF & $\begin{array}{l}\text { 抗 SS-A } \\
\text { 抗体 }\end{array}$ & $\begin{array}{l}\text { 抗 SS-B } \\
\text { 抗体 }\end{array}$ \\
\hline \multirow{2}{*}{ II } & $9 / 21(43)$ & $8 / 21(38)$ & $0 / 19(0)$ & $0 / 19(0)$ \\
III & $5 / 8(63)$ & $4 / 8(50)$ & $4 / 7(57)$ & $2 / 7(29)$ \\
IV & $8 / 12(67)$ & $9 / 12(75)$ & $7 / 8(88)$ & $3 / 8(38)$ \\
\hline
\end{tabular}

$\mathrm{p}<0.001, \operatorname{IgG}: \mathrm{p}<0.001, \operatorname{Ig} \mathrm{M}: \mathrm{p}<0.005)$ (表 4 ).

各病型における血清抗核抗体, RF, 抗 SS-A 抗体, 抗 SS-B 抗体の陽性率

血清抗核抗体，RF が愓性であった症例は，それぞれ II 型: $43 \% \cdot 38 \%$, III 型: 63\% $50 \%$, V 型: 67\% 75 \%であり，II 型においても高值を示し，また，唾影像に よる病型の進行に伴い陽性率が上昇した。抗 SS-A 抗体 および抗 SS-B 抗体が陽性であった拝例は，てれでれII 型： $0 \% \cdot 0 \%$ ， II 型：57\%・29\%，，型： $88 \% \cdot 38 \%$ であり，四，W型では高值を示したか， II 型ではすべて の症例て㓌性だった（表 5 ）.

考察

SS における乾燥症状は，唾液腺および添腺などの外 分泌腺の慢性炎症性变化に由大寸ると考元られている 4) SS こ扮汁る口腔乾燥症状の客観的な柍索法として, 安静時唓液 ${ }^{24,25}$ および刺激唾液分泌量 ${ }^{14,16)}$ の測定などが 行水机ている。支九，唾液腺の基質的変化を検索する方

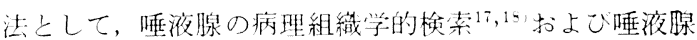
造影法3,4,11 14 が用いられてお门，これらの梌查結果が SS の䛦断上重要視されている。与なわち，SSにおいて は, 健常人之比較して安静時唾液 ${ }^{24,25}$ 方よざ刺激唾液分 泌量 ${ }^{14,15}$ が低下し, かつ, 病状の進行に伴い刺激唾液分 泌量が低下寸る14ことが報告されている。机た，病理組 織学的にも唾液腺の未梢導管周囲のリン人球浸澗の程度 から, SS に拈汁唾液腺の組織学的变化の Grade 分 


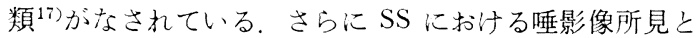
しては腺系像における無数の小円形陰影の存在, いわゆ る branchless fruits-laden tree pattern ${ }^{11}$ が診断上重要 視されている。また福田ら ${ }^{12,13)}$ は, SS にお汁る唾影像 上の初期变化として, 未梢導管 (第 4 分枝) の抎張およ びその周囲の腺系像の小陰影欠損（末梢性斑紋化）が認 められることを報告し, これらの唾影像の SS, 特に初 期 SS の診断にお汁る重要性を指摘している.

他方, SS においても他の自己免疫疾患之同様に種々 の免疫学的異常が出現することが知られている。すなわ ち, Bunim $5^{4}$ はS の患者血清中に抗核抗体および RF が高頻度に認められることを報告している。また Fox ら5および Harley $5^{6)}$ はSS の患者血清中に抗 SS-A 抗 体沶よび抗 SS-B 抗体が認められることを報告し，Talal ら〕も SS に拈いては健常人と比較して血清 IgA, IgG および IgM が上昇することを報告している。ささらに， Morimoto $5^{8)}$ および Adamson $5^{9}$ はSS の患者の末梢 血リンバ球に拈いては，CD 4 陽性細胞/CD 8 陽性細胞 比が上昇することを，また Rodriguez $5^{10}$ は逆にこの 比率が低下することを報告している。しかし， SS にお ける唾影像所見とこれらの免疫学的異常の程度との関連 は明確ではない、本研究においては, 㕰影像による SS の病型と患者の全身的な免疫異常との関連を検討した。

われわれはすでに, 福田らの SS の唾影像による病型 と, SS の臨床所見および唾液腺の病理組織学的所見が 密接に関連することを報告している11). 本研究において も， SS の特異的な唾影像である III，V型のみならず, 初期病型と考えられる II 型を示す症例においても耳下腺 刺激唾液分泌量が低下し，KCS が高率に出現すること が認められた。さらに, 唾影像上の病型と唾液腺の病理 組織学的所見が密接に関連することからも, SSに括け る唾影像の病型が, SS の臨床症状および唾液腺の病理 組織学的変化を反映することを示咬するものと考えられ る. しかも本研究から, 唾影像上の病型の進行に伴い免 疫学的異常所見の陽性率が上昇することが認められた。

すなわち, 病型の進行に伴い末梢血白血球数およびリン

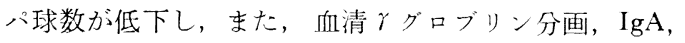
IgG，IgM が增加することが羿められた。しかも， III， V型のみならずII 型においても血清抗核抗体， RF の高 い陽性率が涩められ, さらに病型の進行に伴う陽性率の 上昇も認められた。以上の結果は，唾影像所見が単に SS にお汁る臨床所見および唾液腺の病理組織学的変化 を反㬂するのみならす，全身的な免疫学的検査所見とも 密接に関連することを示㖫するものと思われる。また，

III，型のみならずII 型もまた SS における甠液腺の変 化と関連する唾影像であることが推測される。

他方，II 型の唾影像を示与症例においては，病理組織 学的に唾液腺に SS を疑わせる变化を認めた症例は $29 \%$ のみであった（III型：88\%，IV型：92\%）。さらに血清
抗 SS-A 抗体および抗 SS-B 抗体が陽性であった症例 は，皿型においてはそれぞれ57\%・29\%，N型において は88\%・38\%と高值であったにもかかわらず，II 型にお いてはすべての症例で陰性であった。また，一般に SS の患者中男性の占める割合は数\%以下であると報告され ている3,26) にもかかわらず，本研究では II 型の症例 21 例 中 4 名 $(19 \%)$ が男性であった（II 型，V型はともに0

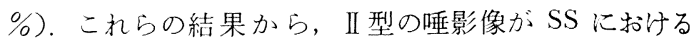
唾液腺の初期変化と関連すると推測されるものの, 必ず しも SS における唾液腺の変化のみを反映するものでは ないことも考えられる。唾影像上の末梢導管の拡張およ び末梢性の斑紋化像が, 唾液腺のいかなる变化を反映す るものであるか現在検索中である。

いずれにせよ以上の結果は, SS にお汁る唾影像所見 が単に SS における臨床所見および唾液腺の病理組織学 的所見を反映するのみならず, 全身的な免疫学的検査所 見とも密接に関連することを示すものと考えられる。

結

語

唾影像から SS を疑わせ, かつ, 他の自己免疫疾患を 伴わない患者を対象として，蹬影像所見と货疫学的検査 所見との関連を比較検討し，以下のような結果を得た。

1. 唾影像上の病型の進行に伴い末梢血白血球数およ びリンパ球数が低下した.

2. 唾影像上の病型の進行に伴い血清 $\gamma$ グロブリン分 画および IgA，IgG，IgM がともに増加し，血清抗核抗 体およびRF の陽性率も上昇した。

3. 血清抗 SS-A 抗体および抗 SS-B 抗体の陽性率は III， $\mathrm{V}$ 型においてい高值を示したが，II 型ではすべての 症例で陰性だった。

本諭文の要旨は昭和 63 年 6 月, 第 42 回日本口腔科学会 総会（札幌）に扣いて発表した。

\section{引用 文 献}

1) Sjögren, H.. Zur Kenntnis der Keratoconjunctivitis sicca (Keratitis filiformis bei hypofunktion der Tranendrusen). Acta Ophthal (Kbh) 11: 1-151 1933.

2) Vanselow, N.: A clinical study of Sjögren's syndrome. Ann Inter Med 58: 124-135 1963.

3) Bloch, K.J., Buchanan, W.W., et al.: Sjögren's syndrome - A clinical, pathological and serological study of 62 cases. Medicine 44: 1872311965.

4) Bunim, J.J.: Clinical, pathologic, and serologic studies in Sjögren's syndrome. Annals Inter Med 61: 509-530 1964. 
5) Fox, R.I., Carstens, S.A., et al.: Use of monoclonal antibodies to analyze peripheral blood and salivary gland lymphocyte subsets in Sjögren's syndrome. Arthritis Rheum 25: 419-426 1982.

6) Harley, J.B., Alexander, E.L., et al.: Anti-Ro (SS-A) and anti-La (SS-B) in patients with Sjögren's syndrome. Arthritis Rheum 29: 1962061986.

7) Talal, N., Sylvester, R.A., et al.: T and B lymphocytes in peripheral blood and tissue lesions in Sjögren's syndrome. J Clin Invest 53: 180-189 1974.

8) Morimoto, C., Reinherz, E.L., et al.. Comparison in $\mathrm{T}$-and B-cell markers in patients with Sjögren's syndrome and Systemic Lupus Erythematosus. Clin Immunol Immunopath 22: 270-278 1982.

9) Adamson, T.C'., Fox, R.I., et al.: Immunohistologic analysis of lymphoid infiltrates in primary Sjögren's syndrome using monoclonal antibodies. J Immunol 130: 203-208 1983.

10) Rodriguez, M.A., Baroja, M.L., et al.. Abnormal immunoglobulin and rheumatoid factor synthesis by blood lymphocytes in patients with primary Sjögren's syndrome. Arthritis Rheum 29: 1446-1455 1986.

11) Blatt, I.M., Rubin, P., et al.: Secretory sialography in diseases of the major salivary gland. Ann Otol Rhin Laryng 65: 295-317 1965.

12）福田博：䀒液腺造影法の実際。富士書院, 札 幌，1986，1-175頁.

13）福田博，杉村俊之，他：唾液腺造影法に関す る研究 (第 3 報) -Sjögren 症候群 11 症例の唾 影像について、口科誌 23：11-27 1974.

14) 斎藤徽, 福田 博, 他: Sjögren 症候群に市 ける唾液腺造影像の再検討. 日口外誌 34：1970 -1975 1988.

15) Shannon, I.L., Prigmore, J.R., et al.: Modified Carlson-Crittenden device for the collection of parotid fluid. J Dent Res 41: 778-783 1962.

16）松田曙美, 有末 真, 他: 人哑液の生理学的研 究 (第一報) 健康人唾液の分泌量及び性状につ いて。 口科誌 33: 8271984.

17) Chisholm, D.M. and Mason, D.K.: Labial salivary gland biopsy in Sjögren's disease. J Clin Path 21: 656-660 1968.

18) Takeda, Y.: Histopathological studies of the labial salivary glands in patient with Sjögren's syndrome Part 1: Light microscopic study. Bull Tokyo Med Dent Univ 27: 9-41 1980.

19）金井泉，金井正光：臨床検査法提要改訂第29 版，金原出版，東京，1983，1220-1235頁.

20) Fahey, J.L. and McKelvey, E.M.:Quantitative determination of serum immunoglobulins in antibody-agar plates. J Immunol 94: 84-90 1965.

21) Moroi, Y., Peebles, C., et al.: Autoantibody to centromore (kinetochore) in scleroderma sera. Proc Natl Acad Sci LS.1 77: 1627-1631 1980.

22) Singer, J.M. and Plotz, C.M.: Slide latex fixation test. A simple screening method for the diagnosis of rheumatoid arthritis. JAMA 168: 180-181 1958.

23) Scopelitis, E., Biundo, J.J., et al.: Anti-SS-A antibody and other antinuclear antibody in systemic lupus erythematosus. Arthritis Rheum 23: 287-293 1980.

24) Ben-Aryeh, H., Spielman, A., et al.: Sialochemistry for diagnosis of Sjögren's syndrome in xerostomic patients. Oral Surg 52: 487-490 1981.

25) Stuchell, R.N., Mandel, I.D., et al.. Clinical utilization of sialochemistry in Sjögren's syndrome. J Oral Pathol 13: 303-309 1984.

26) 大藤 真, 宮脇昌二: Mikliz 病加 5 Sjögren 症 候群まで。免疫と疾患 6：351-355 1983. 